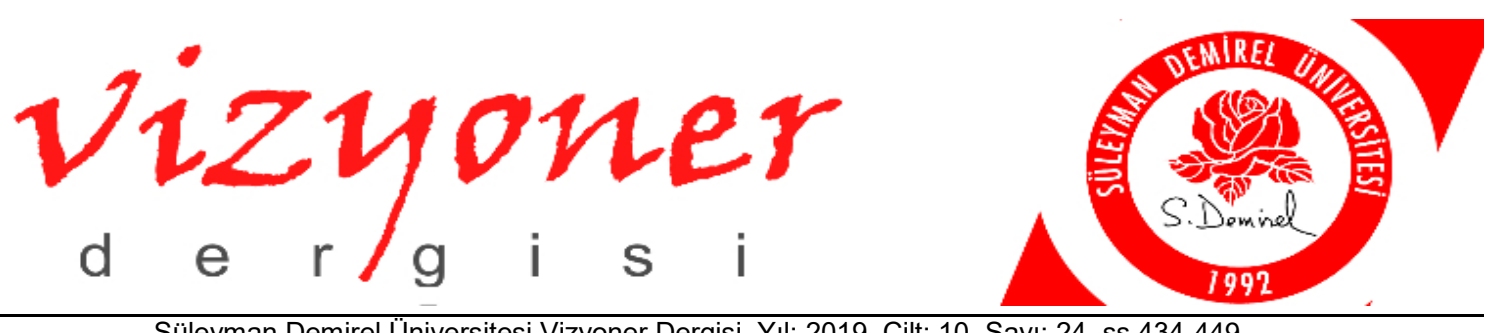

Süleyman Demirel Üniversitesi Vizyoner Dergisi, Yıl: 2019, Cilt: 10, Sayı: 24, ss.434-449. Suleyman Demirel University Visionary Journal, Year: 2019, Volume: 10, Number: 24, pp.434-449.

\title{
BRICS: BİR ALTERNATIF DÜZEN ARAYIŞI MI?
}

\section{BRICS: IS IT A SEARCH FOR AN ALTERNATIVE ORDER?}

\author{
Arş. Gör. Murat POYRAZ1
}

ÖZ

Soğuk Savaş sonrası uluslararası sistemde Amerika Birleşik Devletleri hegemonik bir konuma gelse ve tek kutuplu bir dünyadan bahsediliyor olsa da sistemin genel yapısı çok kutuplu görünümlü nitelikler de barındırmaktadır. Bu zeminde özellikle 2000'lerden bu yana, dünyanın farklı coğrafyalarında ekonomik gelişmelerine paralel şekilde kendilerini toparlayan ülkelerin bir kısmı, bugün uluslararası sistemden memnuniyetsiz kesimi oluşturmaktadır. Brezilya, Rusya, Hindistan, Çin ve Güney Afrika'dan oluşan BRICS, uluslararası sistemdeki memnuniyetsiz kesimlerden birisidir. Küresel yönetişim sistemine daha çok söz hakkı isteyen BRICS ülkeleri, Dünya Bankası, Uluslararası Para Fonu gibi örgütlerden istediklerini elde edemeyince, kendi aralarında kurumsallaşmaya gitmişlerdir. Ekonomik alanda başlayan kurumsallaşma, Dünya Bankasına karşı New Development Bank, Uluslararası Para Fonuna karşı ise Contingent Reserve Arrangement'ın kurulması ile sonuçlanmıştır. Ayrıca, bu gibi kurumsallaşma girişimleri, Amerikan ve Batı düzenine karşı bir meydan okuma niteliği taşıdığı iddia edilebilir. İşbirliğini genişletmek isteyen BRICS ülkeleri, Amerika Birleşik Devletleri’nin birçok alandaki etkisini kırabilecek güce sahiptir. Bu çalışma söz konusu etki kırma dinamiklerini incelemektedir.

Anahtar Kelimeler: BRICS, Hegemonya, Amerika Birleşik Devletleri, Çin, Rusya.

JEL Sınıflandırma Kodları: P16, P50, P51, Y90.

\begin{abstract}
In the post-Cold War World order, the US enjoys a hegemonic position and the international system appears to be a unipolar one, yet the general structure of the system also includes multi-polarity characteristics. According to this latter point, with economic development some countries show a clear dissatisfaction with the hegemonic character of the US-led world order - among these states the BRICS (Brazil, Russia, India, China and South Africa) countries are the most vocal dissatisfied members of the international system. The BRICS countries, with a demand for a more solid floor in the global governance system, have not been able to benefit from the US-led global organizations including the World Bank (WB) and International Monetary Fund (IMF) and to counterbalance them BRICS countries established New Development Bank (a rival to the WB) and the Contingent Reserve Arrangement (against the IMF). With these and many other instruments the BRICS countries challenge the USled world order and to make this conclusively and break the US influence on the system they want to expand their cooperation among each other. The study examines such endeavours.
\end{abstract}

Keywords: BRICS, Hegemony, United States of America, China, Russia.

JEL Classification Codes: P16, P50, P51, Y90.

\footnotetext{
Recep Tayyip Erdoğan Üniversitesi, İktisadi ve İdari Bilimler Fakültesi, Uluslararası İlişkiler Bölümü, murat.poyraz@erdogan.edu.tr, https:///orcid.org/0000-0002-8352-0241.
} 


\section{GIRIŞS: SOĞUK SAVAŞ SONRASI ULUSLARARASI SISTEM}

Soğuk Savaşın bitmesi ile o zamanki iki kutuplu yapı kendisini tek kutuplu yapıya bırakmıştır. Amerika Birleşik Devletleri (ABD), Sovyet Sovyet Sosyalist Cumhuriyeti Birliği (SSCB) ile girdiği uzun soluklu ve düşük sıcak çatışmalı mücadelede SSCB'nin dağılması ile kazanan taraf olmuş ve uluslararası sistemin yegâne süper gücü haline gelmiştir. Aynı zamanda, yaşanan bu duruma ilaveten, dünya siyaseti açısından beklentilerin yüksek olduğu bir döneme de girilmiştir. Soğuk Savaş sonrası küreselleşme sürecinin beraberinde getirdikleri ile birlikte, serbest ticaretin artacağı, kültürel ilişkilerin gelişeceği, demokratik devletlerin artacağı, uluslararası kurumların daha etkin olacağı ve daha az savaşların yaşanacağı vb. bir dünya ihtimali de artmıştı (Kagan, 2014: 11).

Oluşan bu yeni durumu tanımlamak için Francis Fukuyama “tarihin sonu” ifadesini kullanımış; liberal ideolojinin sosyalist ideolojiye karşı vermiş olduğu savaşı kazanması ve liberal ekonominin evrenselleşme sürecine girmesiyle, tarihin bir mücadele süreci olduğu ve bu mücadelenin de bitmesiyle tarihinde sonunun geldiğini iddia etmiştir (Fukuyama, 1992: 211). Bu aynı zamanda, sosyalizmin liberalizmi yeniden tehdit edemeyeceği anlamına da gelmekteydi. Fukuyama, insanoğlunun belirli alanlarda artık ilerleyemeyeceği ve dünyayı liberal düşüncenin kaplayacağını da öne sürmüştür. Fukuyama'nın öne sürdüğü tezlerin bir kısmının 1990’ların başında işler olduğu iddia edilebilir. SSCB'nin dağılması ile ortaya çıkan 15 yeni devlet ve Rusya liberal-kapitalist bloğa entegre olmak fazlaca uğraş verdi. Aynı dönemde Dünya'daki diğer birçok devlet de hali hazırda bu yolda ilerlemeye istekli bir konumdaydı. Dünya ekonomik anlamda kapitalist ekonomilerin ve liberal devlet anlayışının yaygınlaşmaya başladığı bir dönemi tecrübe etmekteydi. İstisnaları olmakla birlikte Rusya'ya ilaveten, diğer BRICS ülkeleri de aynı dönemde benzer şekilde hareket etmiştir.

ABD’nin 41. Başkanı George H.W. Bush ise yeni oluşan uluslararası sistemi "yeni dünya düzeni olarak" adlandırmaktaydı (Arı, 2004: 521). Bu düzen iki kutuplu düzenin sona erdiğini, ABD liderliğinde yeni bir düzenin ortaya çıktığını ifade etmektedir. Bu düzen liberal bir düzen olup, tüm dünya devletlerinin refahının artmasına ve barış içinde yaşamasına işaret etmektedir (Kagan, 2014: 14-75). G. John Ikenberry (2006: 5) ise Soğuk Savaş sonrası dünya düzenini "milliyetçilik, savaş ve ideolojilerin dibe vurduğu, küreselleşmenin kalkınmanın motoru olduğu, demokrasi ve piyasaların dünyanın dört yanında geliştiği liberal dünya düzenin zaferi olarak" tanımlamaktadır.

1990'ların başında oluşan bu durumu anlamaya çalışan araştırmacılardan biri de Samuel Huntington olmuştur. Medeniyetler Çatışması adlı kitabında Huntington (2002: 22-49), Soğuk Savaşın bitmesiyle mücadelelerin yeni, fakat bilinen bir hal kazanacağını, ekonomik, politik, ideolojik çatışmalar yerini medeniyetler arası çatışmaya bırakacağını öngörmüştür. Burada Huntington saydığı dokuz medeniyet ${ }^{2}$ arasında özellikle Batı, İslam ve Sino uygarlığı arasındaki çatışmalar belirleyici olacağını ve bu üç medeniyet arasındaki olası çatışmaların uluslararası ilişkilerin ${ }^{3}$ merkezini oluşturacağını öngörmektedir. Yani, medeniyetlerin içinde barındırdıkları fay hatları bundan sonra çatışmalara sebep olacağını düşünmektedir. Batı'da İslamofobi’nin yaygınlaşması (Aktaş, 2014: 335-35) ve 2000'lerden itibaren uluslararası sistemde ki rekabete Çin- ABD rekabetinin katılmasıyla, Huntington'ın tezi de kısmen doğrulanmıştır.

Robert Kagan (2014: 114-123) ise Tarihin Geri Dönüşü ve Rüyaların Sonu adlı kitabında Samuel Huntington'dan ve Francis Fukuyama'dan farklı olarak, Soğuk Savaş bitse bile liberal demokrasinin ${ }^{4}$ karşısındaki düşman değişmemiştir. Dünya bundan sonra liberal demokrasiler ve otokrasiler arasındaki mücadeleye sahne olmaya devam edeceğini düşünmektedir. Liberal demokrasiler eğer bu mücadeleyi kazanmak istiyorlarsa, kendi aralarındaki safları sıklaştırıp, otokrasilere karşı ortak tutum sergilemeli ve kendi ideolojilerini dünya çapında yayma çalışmalılardır. Böyle bir duruma, bazı BRICS ülkeleri (otokrasiler) ${ }^{5}$ ve Batı medeniyeti (liberal demokrasiler) arasındaki mücadele örnek olarak gösterilebilir. Bu durumda çalışmanın daha sonraki kısmında incelemeye tabi tutulmuştur.

2 Dokuz medeniyet Sino, İslam, Japon, Hindu, Batı Avrupa, Kuzey Amerika, Ortodoks, Latin Amerika ve Afrika’dan oluşmaktadır.

Bu çalışmada uluslararası ilişkiler kavramı, ilk harfleri büyük yazıldığında bir disipline, ilk harfleri küçük yazıldığında ise sadece bir ilişki türüne işaret etmektedir.

4 Kagan, her ne kadar Batı'yı liberal demokrasiler olarak nitelendirse de Batı'da ırkçılığın ve İslamofobi’nin arttığı, aynı zamanda farklılıkları kabul etmekte zorlanan aşırıcılık yanlısı partilerin önemli oranda güç kazanabildiği bir durumun da söz konusu olduğuna dikkat edilmesi gerekir.

5 Burada Kagan'ın tasnifi, çok genel bir ifadeyi kapsamaktadır. Ki BRICS içinde otokrasi olarak nitelendirilemeyecek ülkelerde bulunmaktadir. 
John Mearsheimer ise Soğuk Savaş sonrası durumu milliyetçiliğin ve etnik çatışmaların artacağı bir durum olarak görmüştür (Merasheimer, 1990: 5-56). Soğuk Savaş sonrası sistemi aynı sarkacın iki ucu olarak düşünürsek hem iyimser düşünceler hem de kötümser düşünceler gerçekleşmiştir. Bir taraftan ülkeler küreselleşme sürecinden faydalanıyor ve demokratik ülke sayısı artış gösterirken, diğer taraftan Yugoslavya'nın parçalanma süreci ile birlikte Bosna Hersek, Hırvatistan, Slovenya ve Sırbistan'da yaşanılan milliyetçi ve etnik çatışmalar görülmektedir. Rusya Federasyonu ve arka bahçesinde, Uzak Doğu'da ve Ortadoğu'da otokrasi anlayışına sahip yönetimler de aynı zamanda kendilerini toparlamaya ve sisteme entegre olmaya devam etmektedirler.

1990'lardaki düzen ABD’nin mutlak hegemon güç konumunda olduğu tek kutuplu düzen olduğu göz önüne alınırsa, Soğuk Savaş’tan sonra Uzan Doğu'da, Güney Asya'da, Latin Amerika'da ve Ortadoğu'da birtakım devletler yakaladıkları yüksek ekonomik hızları ile birlikte uluslararası alanda görünür olmaya başladılar. Rosalie Chen'in ifade ettiği gibi uluslararası sistem "bir süper güç ve birçok büyük güçten” oluşmaya başladı (Chen, 2003: 287). 2000’ler ile birlikte artık, tek bir gücün olduğu dünya düzeninden değil birçok gücün etkin olabileceği bir dünya düzenine doğru gidildiği iddia edilebilir.

Bu süreçle birlikte, ABD hegemonyası zayıfladığı ve öncülüğünü yaptığı uluslararası düzenin tehdit altında olup olmadığı tartışılmaya başlandı. Burada taşları yerinden oynatabilecek en önemli gruplardan ${ }^{6}$ biri olan BRICS göz önüne çıkmaya başladı. 2000'den sonraki süreçte BRICS ülkeleri sahip oldukları birtakım özellikler ile birlikte artık daha görünür olmaya başlamışlardır.

$\mathrm{Bu}$ çalışmada, BRICS ülkelerinin küresel yönetişim de yeterince etkili olamadıkları, bundan dolayı da memnuniyetsiz durumda oldukları iddia edilmektedir. BRICS ülkeleri bir yandan sistemin kendilerine sunduğu nimetlerden yararlanırken, aynı zamanda sistem içerisinde belirleyici konuma yükselmek istemektedir. BRICS ülkelerinin uluslararası sisteme bakışları ve ABD hegemonyasına yönelik sorgulamaları, uluslararası ilişkilerde ve sistemde belirleyici olmak istemelerinden dolayı olduğu ifade edilebilir.

Bu çalışmada öncelikli olarak BRICS'in ortaya çıkması değerlendirilecektir. Sonrasında, BRICS'in uluslararası sistemdeki taşıdığı potansiyele dikkat çekilerek, yer yer ABD ile kıyaslaması yapılacaktır. Dördüncü bölümde ise ABD hegemonyasının düşüp düşmediği tartışılacak, bunu takip eden bölümlerde ise BRICS ülkelerinin görmek istedikleri uluslararası sistem ve bu sisteme yönelik eleştiriler ortaya konulmaya çalışılacaktır. Sonuç bölümünde ise, BRICS'in bir alternatif düzen önerip önermediği, Rusya ve Çin'in Güvenlik Konseyi üyeleri olmalarına rağmen neden üye sayısında ve oy niteliğinde reform istedikleri gibi sorulara çalışma konusu kapsamında cevap sunulmaya çalışılacaktır.

\section{BRICS’IN DOĞUSU}

BRICS ülkeleri Brezilya, Rusya, Hindistan, Çin ve Güney Afrika'dan oluşmaktadır. BRICS kısaltması ilgili ülkelerin İngilizce kısaltmalarından oluşmaktadır. BRIC kısaltmasını ilk defa 2001 yılında Goldman Sachs yönetim kurulu başkanı Jim O’Neill tarafından hazırlanan 'Building Better Global Economic BRICs' raporunda kullanılmıştır (O'Neill, 2001: 1). Daha sonraları farklı araştırmacılar tarafından 'dörtler grubu', 'big four', 'kare ası' (Elbasan, 2011), 'küresel güney' (Araz, 2015), 'büyüyen güçler' (Chris ve Vieira, 2005: 1077-1095), bölgesel güçler' (Ghosh, Havlik, Polawski-Ribero, ve Urban, 2009: 4-8), 'belirsiz güçler' (Maull, 2006: 68-77), 'yeni titanlar' (Economist, 2006), 'bir artı dört' (Rieck, 2016) şeklinde isimlendirilse de gruba 2011 y1lında Güney Afrika'nın girmesi ile BRICS adını almıştır. Dünya genelinde en bilindik isim de budur. BRICS kısaltması İngilizcedeki brick (tuğla) kelimesi ile benzeştirilerek bu ülkelerin bir ekonomik düzen oluşturulacağ öngörülmektedir (BBC, 2015).

\footnotetext{
6 BRICS dışında, BRICS'le ekonomik gelişim açısından aynı safta değerlendirilen bazı gruplar şunlardır:

N-11: Bangladeş-Mısır-Endonezya-İran-Güney Kore-Meksika-Nijerya-Pakistan-Filipinler-Türkiye-Vietnam;

CIVETS: Kolombiya-Endonezya-Vietnam-Misır-Türkiye-Güney Afrika

MINT: Meksika-Endonezya-Nijerya-Türkiye

MIST: Meksika-Endonezya-Güney Kore- Türkiye

EAGLEs: Çin-Hindistan-Brezilya-Endonezya-Güney Kore-Rusya-Meksika-Mısır-Tayvan-Türkiye

3G: Bangladeş-Çin-Mısır-Hindistan-Endonezya-Irak-Moğolistan-Nijerya-Filipinler-Sri Lanka-Vietnam

E7: Türkiye-Rusya-Çin-Endonezya-Hindistan-Meksika-Brezilya

SAMI: Suudi Arabistan-Türkiye-Malezya-Endonezya
} 
BRICS 2001'de Jim O’Neill tarafından resmi olmayan bir grup olarak ortaya atılmıştır. BRICS ülkeleri 5 yıl sonra ilk defa Birleşmiş Milletler (BM) çatısı altında 61. Dönem Genel Toplantısı'nda dışişleri bakanları seviyesinde toplanarak BRICS için resmi temaslarda bulunmuşlardır (Sputniknews, 2017). Ardından 2008 yılında G8'de bir araya gelen ilgili ülkeler, 2009 yılı için aralarındaki iş birliğini güçlendirmek ve ortak problemlere çözüm bulabilmek amaciyla bir platform oluşturmaya karar verdiler. 1 yıl sonra Rusya, Çin, Hindistan ve Brezilya, Rusya'nın Yekaterinburg kentinde ilk zirvede bir araya gelmişlerdir (Anadolu Ajansı, 2017). Bu zirveden 2019'a kadar her y1l ilgili ülkelerin birinde toplamda 10 zirve düzenlenmiştir.

BRICS ülkelerinin bir araya gelmesinde bazı faktörler etkili olmuştur. 2008'de yaşanan ekonomik kriz BRICS ülkelerin bir araya gelmesinde itici güç olmuştur. Yine, Uluslararası Para Fonu (IMF) karar alma sürecinde ABD’nin sahip olduğu 16.54'lük oy ağırlığı hakkına sahip olması (Çelik, 2017: 311) ve Dünya Bankası (WB) grubunda Guvernörler Konseyi'nde ABD’nin sahip olduğu 16.36'lık oy gücü ile karar alma sürecindeki etkinliği ilgili ülkelerin bir araya gelmesinde etkili olmuştur (Ateş, 2012: 190-191). ABD’nin ilgili iki ekonomik kuruluşlarda sahip olduğu oy oranı ile tek başına veto hakkını elinde bulundurmaktadır. Çünkü her iki kuruluşta karar alma oran \%85dir (Çelik, 2017, 312-320). Bu nedenle, ABD’nin istemediği hiçbir tasarı geçememekte, ilgili kuruluşlar ABD’nin iki dudağı arasına mahkûm kalmaktadır.

\section{BRICS'IN ÖNEMI}

Andrew Hurrell'e (2006:1-2) göre BRICS ülkeleri dört noktada dikkat çekicidir. İlk olarak BRICS ülkeleri uluslararası düzeni etkileyebilecek ekonomik, askeri ve politik kaynaklara sahiptir. İkinci olarak, BRICS ülkeleri kendilerinin küresel yönetişimde daha çok yer bulmaları gerektiğine inanıyor olmalarıdır. Üçüncü olarak, bu ülkeler iş birliğini geliştirmek için kendi aralarında resmi kanallar oluşturmasıdır. Dördüncü olarak neo-liberal ve kapitalist düzende, BRICS ülkeleri bazen sahip oldukları karşıt duruş ile ilk kuşak büyüyen güçlerden farklı oldukları söylenmektedir.

Politik alanda BRICS ülkeleri bir grup olarak genellikle beraber hareket etme eğilimi sergilerler. Yapılan bir araştırmaya göre, BRICS ülkeleri 1992- 2014 yılları arasında BM Genel Kurulunda tartışılan konulara ilişkin olarak yapılan oylamalarda genellikle benzer yönde oy kullandıkları saptanmıştır (Montenegro ve Mesquita, 2017: 1). Rusya’nın Kırımı ilhakından sonra Brezilya, Çin, Hindistan, Güney Afrika doğrudan Rusya'yı kınayacak bir BM Genel Kurulu kararından kaçındıkları gözlemlenmiştir (Stuenkel, 2016: 44). Başka bir örnek ise NATO’nun Libya'ya yaptığı müdahaleden sonrada Libya'ya uygulanan askeri gücü kınadıklarını belirtmişlerdir (Elbasan, 2011). Fakat, Koruma Sorumluluğu (R2P) kapsamında Suriye'ye müdahale gündeme geldiğinde BRICS ülkeleri zorlayıcı önlemlere karşı mesafeli olsalar da Brezilya, Güney Afrika ve Hindistan'ın müdahaleye biraz daha yakın oldukları düşünülmektedir (Odeyemi, 2015: 229). Ayrıca, daha kapsayıcı ve daha demokratik bir küresel yönetim için BM Güvenlik Konseyinde reform yapılmasını istemektedirler. Dünya da uluslararası dengeler değiştiği için BM Güvenlik Konseyinde ki daimî üyelerinin sayısının arttırılması ve Güvenlik Konseyindeki 5 kalıcı üyenin oy haklarındaki niteliklere ilişkin yeni düzenlemeler istemektedirler. Ayrıca, küresel meselelerin çözümünde kendilerinin de katılabileceğini bu yüzden de sürekli bir diyalogdan yana tutum sergilemektedirler (Jash, 2017).

BRICS ülkelerinin gelecek yıllarda dünya ekonomisinde nasıl bir gidişat izleyeceği sorusu üzerine Goldman Sach'de hazırlanan raporda, ilgili ülkelerin gelecek yıllarda hâkim ekonomik güç olacakları ve güç paylaşımı ile kurulu dünya düzenini yeniden şekillendirebileceği ifade edilmiştir (O'Neill, 2001:1). Goldman Sachs'1n 2035 yılı tahminlerine göre, BRIC ekonomileri G7 ekonomilerini geride bırakacağı öngörülmektedir (Öniş ve Kutlay, 2015 : 20). Yine Goldman Sachs tarafindan 2003 yılında yayımlanan 'Dreaming With BRICs: The Path to 2050' adlı raporda, 2050 yılında BRIC ülkeleri dünyanın ilk 10 ekonomisinde olacağı tahmin edilmektedir. Çin dünyanın en büyük ekonomisi olurken, üçüncü ekonominin Hindistan, dördüncü ekonominin Brezilya ve altıncı ekonominin Rusya olacağı tahmin edilmektedir (Wilson ve Purushothaman, 2003: 1).

Bu ülkelerin sahip oldukları gayrisafi yurtiçi hasılalarına, kişi başına düşen milli gelirlerine, nüfuslarına, yaptıkları askeri harcamalara, dünyada kapladıkları alana, sahip oldukları doğalgaz ve petrole bakarak BRICS hakkında fikirler edinebiliriz. Ayrıca işçi ücretlerinin düşük olması, emek piyasalarının kötü olması, genç ve artan bir nüfusa sahip olmaları, doğrudan yabancı sermaye yatırımı çekebilmeleri, düşük üretim maliyetleri gibi faktörler de ilgili ülkelerin neden önem arz ettiğini aktarabilir (Ağır ve Yıldırım, 2015: 39). Ek olarak, BRICS ülkelerin belirli uluslararası meselelerdeki tutumları, söylemleri ve kurdukları resmî kurumları ile bugün uluslararası sistemde dikkat çekmeye başlamıştır. 
2017 Nisan ayı IMF verilerine göre, ilgili ülkelerin dünya sıralamasındaki gayrisafi yurtiçi hasılalarına bakacak olursak Çin 23,194,411 (\%18,3) trilyon dolar ile birinci, Hindistan 9,489,302 (\%7.49) trilyon dolar ile üçüncü, Rusya 3,938,001 (\%3.11) trilyon dolar ile altınc1, Brezilya 3,216,031 (\%2.54) trilyon dolar ile sekizinci, Güney Afrika 761,926 (\%0.601) trilyon dolar ile otuzuncu sırada yer almaktadır. BRICS ülkeleri 1990'larda dünya gayrisafi yurtiçi hasılasının \%10'na hükmederken (Amrita, 2017), BRICS ülkeleri şu an için dünya gayrisafi yurtiçi hasılasının \%40’ndan fazlasını işgal etmektedir (Statistics Time, 2017). Gayrisafi yurtiçi hasıla bakımından Çin diğer BRICS ülkelerini geride bırakarak hem dünyada hem de BRICS grubunda birinci sırada yer almaktadır. $\mathrm{Bu}$ durum küresel ticarette ve ekonomide BRICS grubunun önemini ortaya koymaktadır.

IMF verilerine göre, ilgili ülkelerin kişi başına düşen milli gelirine baktığımız zaman Rusya 27,466\$ ile BRICS ülkeleri arasında birinci sırada yer almaktadır. Daha sonra sırasıyla, 16,67\$ ile Çin ikinci, 15,485\$ ile Brezilya üçüncü, 13,409\$ ile Güney Afrika dördüncü ve 7,153\$ ile Hindistan BRICS ülkeleri arasında sonuncu konumdadır (Statistics Time, 2017).

2017 verilerine göre BRICS ülkelerinin dünya nüfusun açısından yerine bakacak olursak, Çin 1,409,517,397 $(\% 18,67)$ milyar nüfusu ile birinci sırada yer almaktadır. Ardından 1,339,180,127 $(\% 17,74)$ milyar nüfusu ile Hindistan ikinci sırada, 209,288,278 (\%2,77) milyon nüfusu ile Brezilya beşinci, 143,989,754 (\%1,91) milyon nüfusu ile Rusya dokuzuncu, 56,717,156 $(\% 0,75)$ milyon nüfusu ile Güney Afrika yirmi beşinci sırada yer almaktadır. Toplamda dünya nüfusunun \%41,8'ni oluşturmaktadırlar (Worldometers, 2018). Sadece Çin ve Hindistan dünya nüfusunun üçte birinden fazlasını oluşturması dikkat çekicidir.

Askeri masraflar bakımından 2016 verilerine göre BRICS ülkeleri sıralamasına bakıldığı zaman, Çin gayri safi yurtiçi hasılasının \% 1,9'nu harcayarak dünyada askeri harcamalar bakımından ikinci sırada (\%13) bulunmaktadır. Ardından Rusya gayrisafi yurtiçi hasılasının \%5,3'nü harcayarak dünya sıralamasında üçüncü sırada $(\% 4,1)$, Hindistan gayrisafi yurtiçi hasılasının \%2,5'ni harcayarak altıncı sırada $(\% 3,3)$, Brezilya gayrisafi yurtiçi hasılasının \%1,3'ni harcayarak dünya sıralamasında on ikinci sırada $(\% 1,4)$, Güney Afrika gayrisafi hasılasının yüzde \%1,1 'ni harcayarak dünya sıralamasında kırk birinci sırada bulunmaktadır (Sipri, 2017). Toplam BRICS ülkelerinin askeri harcamaları yaklaşık \%22 ye tekabül etse de ABD'nin tek başına yaptığı harcamayı geçememektedir. Yine bu bağlamda, dünyadaki nükleer silah sayısına sahip 9 devlet $^{7}$ arasından Rusya ABD'yi geçerek birinci sırada bulunmaktadır. BRICS grubu içerisinde Rusya, Çin ve Hindistan nükleer silaha sahiptir (Routley, 2014).

Dünyada kapladıkları yüz ölçümü açısından bakıldığında, Rusya 17,098,242 km2 alan $(\% 11,5)$ ile hem dünyada hem de BRICS grubu içerisinde birinci sırada yer almaktadır. Ardından Çin 9.598,094 $(\% 6,4) \mathrm{km} 2$ alan ile BRICS grubu içerisinde ikinci dünyada beşinci sırada bulunmaktadır. Brezilya 8,513,877 (\%5,7) km2 alan ile BRICS grubu içerisinde üçüncü dünyada altıncı sırada bulunmaktadır. Ardından Hindistan 3,287,263 (\%2,3) km2 alan ile BRICS grubu içerisinde dördüncü dünyada sekizinci sırada yer alır. Güney Afrika ise 1,221,037 (\%0,82) km2 alan ile BRICS grubu içerisinde sonuncu, dünyada yirmi yedinci sırada yer almaktadır (CIA, 2009). Toplamda \%26,72 ile BRICS dünya coğrafyasının $1 / 4$ 'den daha fazla yer kaplamaktadır.

BRICS ülkeleri doğal gaz rezervleri bakımından incelendiğinde, Rusya 47,8 trilyon metreküp kanıtlanmış rezervi ile dünyada birinci sırada yer almaktadır. Ardından Çin 5,1 trilyon metre küp ile dünya sıralamasında onuncu, Hindistan sahip olduğu 1,2 trilyon metre küp ile yirmi dördüncü, 429,9 milyar metreküp ile Brezilya otuz dördüncü, son olarak 15 milyon metreküp kanıtlanmış rezervi ile Güney Afrika dünya sıralamasında yetmiş dokuzuncudur (CIA, 2017). Yukarıdaki verilere bakarak BRICS grubu içerisinde kanıtlanmış doğal gaz rezervine en fazla Rusya sahiptir. Ardından sırasıyla Çin, Hindistan, Brezilya ve Güney Afrika gelmektedir.

BRICS ülkeleri petrol rezervleri açısından da Rusya sahip olduğu 80 milyar metreküp rezervi ile dünya sıralamasında sekizinci konumundadır. Ardından Çin 25,6 milyar metreküp rezervi ile dünyada on üçüncü, 13 milyar metreküp rezerve sahip Brezilya on beşinci, 4,6 milyar metre küp rezervi ile Hindistan yirmi beşinci, 15 milyon metreküp rezervi ile Güney Afrika seksen sekizinci konumdadır (CIA, 2017). Doğalgaz da olduğu gibi petrolde de Rusya BRICS grubu içerisinde birinci sıradadır. Bu bakımdan Rusya'nın grubun gaz ve petrol tedarikçisi olarak görülebilir. Ardından Çin, Brezilya Hindistan ve Güney Afrika gelmektedir.

Bu 9 devlet şunlardır: Rusya, ABD, Fransa, Çin, İngiltere, Pakistan, Hindistan, İsrail ve Kuzey Kore’dir. 


\section{AMERIKKAN HEGOMONYASI'NIN DÜŞÜŞÜ}

ABD’nin hegemonyasının düşüp düşmediğine dair tartışmalar Soğuk Savaş dönemine kadar götürülebilir (Hensman ve Correggia, 2005: 1091-1095). 1970'li yıllarda Vietnam'ın ABD'nde yarattığı etkilerle birlikte, Helsinki sürecinin yaşanması ve iki bloğun zımni olarak birbirlerinin etki alanlarını kabul etmeleri ABD'nin hegemonyasında düşüş olarak algılanmıştır. Fakat Süveyş Krizi’nin yaşanması ve ABD’ye olan etkileri (Sayın, 2016:65-70), Fransa'nın 1966'da Kuzey Atlantik Antlaşması Örgütü'nden (NATO) çıkması (Ateş, 2012: 348) gibi durumları göz önüne alarak, ABD hegemonyasının düşüşe başladığı tarihi daha da geriye götürebiliriz.

Soğuk Savaş'ın sona ermesi ile ilgili tartışmalara mola verilse de (Doğan, 2017: 99), Wallerstein'in de belirttiği gibi, 9/11 olaylarının yaşanması ertesinde ABD'nin Afganistan ve Irak'a yaptığı müdahaleler (Wallerstein, 2002: 60-68) ve bunların neden olduğu sonuçlar ABD hegemonyasının düşüşü olarak görülmüştür. Bu açıdan bakıldığ1 zaman, ABD’nin sahip olduğu militarizmi kullanış şekli hegemonyanın düşüşünde önemli rol oynamıştır (Isernia ve Fabrinni, 2007: 187-215). Odom, ayrıca ABD’nin Irak ve Afganistan savaşlarında tek taraflı ve saldırgan tutumu ile müttefiklerinin de desteğini yitirdiğini belirtmiştir (Odom, 2007: 404-411). Mevcut savaş sonrasında, Amerikan askerlerinin yaptığı hareketler, Amerika'nın Irak'a girerken söylediği nedenlerin yalan olduğu ortaya çıkması dünya da Amerika'nın prestijini ve saygınlığını sarsmıştır (Grigoriadis, 2010: 51-66).

Joseph Nye (2015: 15-17) devletler güç açısından tepe noktasına ulaştıklarında, tekradan düşüşe geçme süreci yaşayacağını iddia etmiştir. Bu noktada, Çin'in gayrisafi yurtiçi hasıla bakımından 2016'da ABD'yi geçmiş olması, ABD'nin ekonomik olarak gerilemeye başladığını söyleyebiliriz. ABD’nin gerilemesi bir noktada dişsal güçteki göreli düşüşte ve diğerlerin yükseliş yaşaması ile doğrudan ilişkisi vardır (Nye, 2015: 18). Bu bakımdan, Fareed Zakaria'nın dediği gibi, “... ABD’nin gerilemesi değil, ondan başka herkesin yükselmesi...” hegemonyanın gerilemesinde büyük rol oynamıştır (Zakaria, 2008 :1). Ona göre, “ABD, büyük ve küçük pek çok alanda zirvedeki konumunu kaybetmiştir ya da kaybetmektedir; ancak dünyanın tek olmasa da en baskın süper gücü olarak politik-askeri konumunu muhafaza etmeyi sürdürüyor ve sürdürecek gibi görünüyor.” (Zakaria, 2008: 4-5). Buna rağmen ABD, ekonomi ile ilgili uluslararası örgütlerde de etkinliğini korumaya devam etmektedir. Fakat, Erkin Ekrem'e göre, “Dünya ekonomisi giderek Doğu ve Güney’e bağımlı kalacaktır. Kalkınmakta olan ülkeler, küresel ekonomik büyümenin \%70’ini teşkil edecektir. Çin'in katkısı ise ABD’nin 1,5 katı olacaktır. 2025 yılına doğru Çin'in küresel ekonomik katkısı 1/3'ü oluşturacak” (Ekrem, 2013). Böyle bir durumun gerçekleşmesi ile, ABD’nin ilgili ekonomik kuruluşlarda ki etkinliği de zayıflamaya başlayacaktır.

Neo-liberalizmin kendi nüvesinde bulundurduğu birtakım özellikler ABD’nin hegemonyasının düşüşünde etkili olmuştur. Serbest ticaret ahlakı, piyasalardaki serbestlik anlayışı ve kar-kazanç düşüncesi, bireyin özgürlüğü gibi özellikler önemli rol oynamıştır. Çin'in serbest piyasalara geçiş süreci ile birlikte cazip ticari düzenlemeler ve ucuz iş ücretleri ekonomik aktörlerin Çin'e doğru hareket etmesine sebep olmuştur. Bu noktadan sonra Çin'in serbest ticareti, Çin'in yükselmesinde başat rolü oynamıştır. Bu noktada artık Amerikan ekonomisinin değil, Çin ekonomisinin hapşırdığında dünyanın soğuk algınlığa kapılacağı bir dünyaya doğru yol kat edileceği öngörülmektedir. Bunun farkında olan ABD ise 'döngü kırıcı' (Uzgel, 2017) olarak hareket ederek, pozisyonunu korumak istemektedir. Çin'deki değişimi fark eden Obama, 2009'da ABD-Çin ilişkilerini 'rakip' (competitor) olarak tanımlarken, 2012'de 'düşman olan rakip'i (adversary) kullanmıştır (Ekrem, 2012: 40-45). Yine 2012'de ABD Savunma Bakanı Leon E. Panetta'nın Çin için 'yeniden dengeleme' stratejisinden bahsetmiştir (Manyin vd., 2012: 1). Bu stratejiye göre, Soğuk Savaş’tan sonra, dengelenmesi gereken en önemli güç Çin olarak gözükmektedir.

Amerikan karşıtlığının dünya genelinde yaygınlaşması da Amerikan hegemonyasının düşüşüne katkıda bulunmuştur (Kagan, 2014: 107). Amerikan karşıtlığg, Amerikan toplumuna yönelik bir karşıtlık değil, Amerikan'ın politik ve ekonomik siyasetine yani ABD sisteminin kendisine yönelik bir karşıtlıktır (Nairn, 2002:103-104). Pew Araştırma Merkezinde Ağustos 2017 yılında yayınlanan bir araştırmaya göre, ABD’yi dünyada tehdit olarak gören ülke toplumları listesinin ilk 5 sıralaması şu şekildedir: Türkiye (\%72), Güney Kore (\%70), Japonya (\%62), Meksika (\%61), İspanya (\%59) (Pew Research Center, 2017). İlk sıradakileri ABD’nin müttefiki olarak düşünürsek, Amerikan karşıtlığı Donald John Trump ile birlikte daha artacağı öngörülebilir. 7 Müslüman ülke vatandaşlarına ülkeye girişini engellemeye yönelik aldığı karar $^{8}$ (BBC, 2018), Meksika sınırına duvar yapma kararlılığı (Habertürk, 2018), Çin ve İran'a karşı uyguladığı politikalar (Sputniknews, 2018), Almanya AB'yi sömürüyor demesi (Gümüş, 2018), NATO’nun işe yaramadığını söylemesi (Dünya, 2018), NATO

8 İlgili ülkeler: Irak, Suriye, Yemen, İran, Sudan, Somali ve Libya 
zirvesin 'de Karadağ Başkanı Duşko Markoviç'i iterek öne geçmesi (Euronews, 2017) dünyadaki Amerikan karşıtlı̆̆ını arttıracaktır.

ABD Ulusal İstihbarat Konseyi'nin hazırladığı ve Aralık 2012'de yayımlanan 'Küresel Eğilimler 2030: Alternatif Dünyalar' adlı raporuna göre ABD'nin hegemonyasının 2030'a doğru sona erebilecek olmasından bahsetmektedir. Dünyada yükselen güçlerin yeni kutuplar oluşturduğu, bu kutuplardan en dikkat çekici olanın ise Çin olduğunu belirtmişlerdir. Güç intikalinin ABD'den Çin'e doğru olacağı tahmin edilmektedir. Fakat, Çin'in ABD’nin yerini alamayacağı veya hiçbir gücün onun yerini alamayacağını iddia edenlerde bulunmaktadır. İkinci duruma göre, uluslararası ilişkiler hegemonsuz bir dünyada devam edecektir (AREM, 2012).

Yukarıdaki raporla bağlantılı olarak, BRICS ülkeleri içerisinde Çin'in Amerikan hegemonyasını devirebileceği ve kendi sistemini yaratacağı öngörülmektedir. Buradaki düşünce 19. yy. da Almanya'nın yükselişi ile Britanya'nın hegemonyasındaki zayıflamadan gelmektedir. Aynı döngünün bu sefer Çin'in yükselişi ile Amerikan hegemonyasının zayıflayacağı iddia edilmektedir (Doğan, 199-210). Fakat Çin'in birçok alanda pozitif gelişme sağlamasına rağmen, hegemonya olabilmek için hala eksiklikleri vardır. Örneğin, Çin'in Amerika'ya göre dünyaya verebilecekleri daha azdır. "Çin'in ABD’nin yarattı̆̆ı avantaj, yani bilim, teknoloji, bilim adamları, küresel askeri gücü, demokrasi ve insan hakları değerleriyle birlikte dünyayı etkileyen Amerikan kültürü gibi özelliklere sahip olması gerekmektedir. Çin'in en büyük eksiği ise yumuşak gücü (soft power) olmamasıdır.” (Ekrem, 2013).

Burada dikkat çekilecek önemli bir husus bulunmaktadır. Her ne kadar birçok alanda ABD gerileme yaşayacağı öngörülse de neo-liberal düzen devam etmektedir. ABD yaptığ 611 milyar dolar $(\% 3,6)$ askeri harcaması, IMF ve WB'deki oy ağırlığg, dünyanın çeşitli yerlerindeki üstleri ve uluslararası örgütlerle kurduğu ittifak ilişkileri, doların uluslararası ticaretteki konumu ile önemli bir konumu işgal etmektedir (Uzgel, 2017). Ayrıca ABD'nin dünyanın en iyi üniversitelerine, akademisyenlerine, bilim adamlarına ve strateji uzmanlarına sahip olduğu düşünülmektedir (Ekrem, 2013). Bu noktada ABD’nin hegemon rolünü üstlenmeye devam edeceği öngörülebilir. Fakat hegemonya sonsuza kadar sürmeyecektir. Çünkü Çin, Rusya, Almanya, Japonya, Hindistan gibi büyüyen güçler mevcut sistemde daha fazla belirleyici olmak isteyeceklerdir. Böyle bir durumda ABD'nin takınacağı tutum belirleyici olacaktır.

\section{BRICS: NASIL BIRR ULUSLARARASI SISTEM?}

BRICS ülkelerinin nasıl bir uluslararası sistem görmek istedikleri ve uluslararası sistemin hangi noktalarda etkisiz kaldığı, en genel itibariyle BRICS zirveleri ile ortaya konulabilir. BRICS zirveleri ülke liderlerinin yılda bir defa BRICS ülke şehirlerinden birinde toplanmasıyla gerçekleştirilen bir platform niteliği taşımaktadır. Bu platformda bir araya gelen ilgili devletler açıklık, şeffaflık, dayanışma, eşitlik, karşılıklı anlayış, kapsamlılık, karşılıklı fayda, çok taraflılık, toprak bütünlügü̈ne saygl, egemenlik, bă̆ımsızlık, iç işlerine karışmama, siyasi bă̆ımsızlık ilkeleri ile kendi aralarında etkileşim gerçekleştirmektedirler.

İlk zirve 16 Temmuz 2009'da Rusya'nın Yekaterinburg şehrinde toplanan BRICS ülkeleri mevcut küresel ekonomiyi, küresel sorunları ve kendi aralarındaki iş birliğini nasıl güçlendireceklerini tartışmışlardır. Zirve sonunda yayınlanan bildiride dikkat çeken 4 durum bulunmaktadır. İlki, Group of 20 (G20) ve BM'ye vurgu yapıldıktan sonra, BRICS ülkelerinin uluslararası finans kuruluşlarında daha çok temsil edilmesi gerektiğini, bu noktada ilgili kuruluşlarda reform yapılması gerekliliğine dikkat çekmektedirler. Buradaki ilgili finans kuruluşları WB ve IMF'ye gönderme yapılarak oy ağırlığının yeniden düzenlenmesini ve birkaç alanda daha reform önerisinde bulunmaktadırlar. İkincisi, demokratik ve uluslararası hukuka, eşitliğe, karşılıklı saygıya, iş birliğine dayanan çok kutuplu dünyaya yapılan vurgudur. Böylelikle BRICS ülkeleri için tek kutuplu düzenin kabul edilmediğini, kendilerinin de dikkate alınması gerektiğine dikkat çekmektedirler. Üçüncüsü doğrudan BM'ye yönelik, dolaylı olarak ise BM Güvenlik Konseyi'ne yönelik mesajdır. BM oynadığı role dikkat çeken BRICS ülkeleri, BM'de kapsamlı değişiklikler yapılmasını istemektedir. Özellikle BM Güvenlik Konseyi’nin etkisizliğine dikkat çekilerek, Güvenlik Konseyin de yapısal değişiklikler önermektedirler. Dördüncü olarak da bazı ülkerdeki yaşanılan sorunlara dikkat çekilmekte ve ilgili kuruluşlara göreve çağırmaktadırlar. Örneğin, uzun süreden beri devam eden İsrail-Filistin çatışmasında BM'nin daha etkin bir rol üstlenebileceğini belirtmektedirler. ${ }^{10} \mathrm{Bu}$

\footnotetext{
94 yılda bir kez ve 16 istihbarat teşkilatı tarafından hazırlanan çalışmaların ilki 1996-97 yıllarında Ulusal İstihbarat Konseyi tarafından yayımlanmıştır. Geleceğe yönelik olarak ABD’nin durumunu ve stratejik hedeflerini ortaya koymaktadır.

10 Burada BRICS ülkeleri her ne kadar BM gibi yapıları etkin olmamakla suçlasada BRICS ülkelerinin bu gibi olaylara karşı politikalarının daha çok söylemsel düzeyde kaldığı düşünülmektedir.
} 
bakımdan, G20, BM gibi uluslararası örgütlerde bir grup olarak beraber hareket etme kararı almışlardır (BRICS Information Centre, 2009). Yapılan ilk zirve BRICS'i anlamamız için önemlidir. İlk zirvede yayınlanan ortak bildiri, genellikle ekonomik meselelere ilişkin olduğu için bu ülkelerin öncelikli olarak ekonomi kaygılarla bir araya geldiğini iddia edilebilir. Ayrıca, ABD’den ve bahsedilen uluslararası örgütlerin işlevsel olmamasından duyulan memnuniyetsizlik de ABD’nin sahip olduğu etkinliği ile ilgilidir.

İkinci zirve, birinci zirvede belirlendiği üzere 16 Nisan 2010'da Brezilya'da gerçekleştirilmiştir. Ortak Vizyon ve Küresel Yönetim başlığı altında toplanan BRICS ülkeleri bazı noktalara dikkat çekmişlerdir. İlki, dünyanın hızlı bir değişim sürecinden geçtiğini ve bu yüzden birçok alandaki küresel yönetişimde değişiklik yapılması gerektiğine vurgu yapılmaktadır. Özellikle BM, WB, IMF gibi örgütlere dolaylı yollardan dikkat çekilerek değişiklik istenmektedir. İkinci olarak kendi aralarındaki iş birliğini ve ticareti arttırmak için yapılacak düzenlemeler ile ulusal para birimlerinin ticarette ve yatırımlarda kullanılmasını ve sektörel iş birliği yapılmasını kararlaştırmışlardır. Böylelikle kendi aralarındaki iş birliğini geliştirerek, ilişkilerini derinleştirebilme fırsatını elde edebilirler. (BRICS Information Centre, 2010).

Üçüncü BRICS zirvesi Çin'in Sanya kentinde toplanmıştır. Sanya Deklarasyonu'nda göze çarpan ilk şey gruba Güney Afrika'nın davet edilmesidir. Öncesinde Meksika’nın ya da Türkiye gibi Müslüman bir ülkenin gruba dahil olması beklenirken, Güney Afrika davet edilmiştir. Güney Afrika'nın yanı sıra diğer ülkelerinde gruba dahil olabileceği izlenimi yaratılarak, diğer ülkelerle birlikte iş birliği yapmaya açık olduklarını bildirmişlerdir. Başka bir husus, yükselen diğer güçlerin uluslararası meselelerde söz sahibi olması gerektiğine dikkat çekmişlerdir. Bu noktada aynı zamanda, Orta Doğuda, Kuzey Afrika ve Batı Afrika'daki başlayan çatışmalar hususunda endişeli olduklarını, bu noktada bağımsızlığa, birliğe ve toprak bütünlüğüne vurgu yaparak bölgeye yapılacak güç müdahalelerine karşı olduklarını bildirmişlerdir. Bölgelerde başlayan gerginliklerin barışçıl bir yöntemle çözülmesi gerektiğini ifade etmişlerdir. İlk defa Sanya deklarasyonunda açık bir şekilde IMF'den duyulan memnuniyetsizlik dile getirilmiş ve reform yapılması gerektiğini belirtmişlerdir. Yine ilk defa doları hedef alarak uluslararası para biriminde reform yapılması gerektiğini vurgulamışlardır (BRICS Information Centre, 2011).

Dördüncü zirve Hindistan'ın Delhi şehrinde 29 Mart 2012 tarihinde gerçekleştirilmiştir. Bu zirvede Güney Afrika gruba kabul edilirken aynı zamanda diğer ülkelerle iş birliğine vurgu yapılmıştır. Farklı olarak, gelişmiş ekonomilerin benimseyeceği makroekonomik ve finansal politikalara dikkat çekilmiştir. IMF'de acilen 2012'deki yıllık toplantıdan önce yönetim ve kota reformu yapılması için çağrıda bulunmuşlardır. Yine ilk defa WB ve IMF'ye yönelik olarak kaynaklarını gelişen ve büyüyen ekonomilere doğru aktarılmasını, kredi maliyetlerinin azaltılmasını ve yenilikçi kredi araçlarının geliştirilmesini istemektedirler. WB ve IMF'deki rahatsızlık dile getirildikten sonra, dünya genelinde yeni bir gelişim bankası kurma fikri tartışılmıştır. Kurulacak banka ile ilgili olarak BRICS ülkeleri ekonomi bankaları bir sonraki zirveye kadar görevlendirilmiştir. BRICS ülkelerinin ticaret bakanları arasında aralarındaki ticareti geliştirmek için ayrıca yıllık zirveler düzenlenmesine karar verilmiştir. Yine bu amaçla İş ve Finans formu oluşturulmuştur. BRICS ülke bankaları arasındaki iş birliği mekanizması altında ulusal para biriminde kredi veren anlaşmayı onaylamışlardır. Siyasi açıdan, Ortadoğu'da uzun süredir devam etmekte olan Arap-İsrail çatışmasında tarafları barış için BM kararlarına, Madrid İlkelerine ve Arap Barış Girişiminin geliştirdiği ilkelere davet etmişlerdir. Yine Filistin ve İsrail arasındaki çatışmaların sonlandırılması için taraflara çağrıda bulunmuşlardır. Açık bir şekilde, ilk defa BM Güvenlik Konseyinde reform yapılmasını istemektedirler. Son olarak zirve sonunda kabul edilen Delhi Hareket Planına göre, ülkelerdeki bakanlıklar arasında uluslararası örgütlerde ve küresel meselelerde birlikte hareket edebilmek için bir uyum öngörülmüştür (BRICS Information Centre, 2012). Özellikle bu zirve ile birlikte, ekonomi alanında iş birliğinin derinleştirilmeye çalışılmak istenmesi dikkat çekicidir. WB'ye karşı bir kurum fikri ise ABD'nin etkinliğine karşı açık bir meydan okuma olarak değerlendirilebilir. Aynı zamanda uluslararası ilişkilerde gündemde olan konularla ilgili olarak ortak görüş ifade etmeleri de iş birliğinin siyasi boyutta da devam edebileceğini göstermektedir.

İlk turun tamamlandığı beşinci zirve 27 Mart 2013'de Güney Afrika'nın Durban şehrinde yapılmıştır. Zirve Afrika'da yapıldığı için Afrika kıtasının gelişimine dikkat çekilmiştir. Güney Afrika'nın gruba dahil olması ile, kurumsallaşma yönünde adımlar atılmıştır. Bu zirvede BRICS ülkeleri arasında kaynak ihtiyacını karşılamak, karşılıklı destek ve finansal istikrarı güçlendirmek için 100 milyar dolar hacimli Koşullu Rezerv Düzenlemesinin (Contingent Reserve Arrangement) (CRA) kurulmasına karar verilmiştir. Yine bir önceki zirvede tartışıldığı üzere, ABD Merkez Bankasından da olumsuz etkilenen BRICS ülkeleri (Ayar, 2014) bu zirvede kalkınma bankası kurmayı kararlaştırmışlardır. Filistin'in BM'ye gözlemci devlet olarak katılmasından dolayı duydukları memnuniyeti dile getirmişlerdir. İran ile ilgili olarak yürütülen nükleer müzakerelerde olası sonuçlara karşı İran'a 
karşı yapılabilecek askeri harekata karşı olduklarını bildirmişlerdir. Bu bağlamda İran'ın nükleer enerjinin barışçıl kullanım hakkına sahip olduklarını belirtmişlerdir (BRICS Information Centre, 2013).

Altıncı zirve Brezilya'nın Fortaleza şehrinde 15 Temmuz 2014'de gerçekleştirilmiştir. Öncelikli olarak, BRICS ekonomilerinin 2008'den sonra ortaklaşa bir şekilde geliştiğini belirtmektedirler. BRICS ülkelerinin ve diğer gelişen ülkelerin bir takım ortak sorunları olduğunu, bunun için beraber hareket etmeleri gerektiğine dikkat çekmektedirler. Bu bakımdan, grubun dar çerçeve de kalmayacağı, daha da genişleyebileceği iddia edilebilir. Altıncı zirve de üç anlaşma imzalanmıştır. İlki, Yeni Kalkınma Bankası'nı (New Development Bank) kuran anlaşmaya imza atmışlardır. Bu noktada kurulacak banka altyapı ve sürdürülebilir gelişme için BRICS ülkeleri ve diğer gelişen ülkeler arasında bir köprü vazifesi görevi göreceğini ve çok taraflı ve bölgesel finans kuruluşlarını tamamlayacağı belirtilmiştir. 100 milyar dolar sermaye ile kurulan NDB pay dağılımı eşitlik temelinde gerçekleştirilecektir. Bankanın ilk başkanı ise Hindistan'dan olmuştur. Bankanın merkezi ise Şangay’da olması kararlaştırılmıştır. İkincisi, bir önceki zirvede kararlaştırılan CRA'yı kuracak anlaşmayı da imzalamışlardır. CRA için sermaye başlangıçta 100 milyar dolar kararlaştırılmıştır. Üçüncü olarak ise BRICS ülkeleri arasında İhracat Kredi ve Garanti Ajansı'nı kurmuşlardır (BRICS Information Centre, 2014).

2014 yılı ile birlikte ekonomi alanında güçlü adımlar atan BRICS ülkeleri kurumsallaşma açısından önemli adımlar atmışlardır. Kendi sistemlerini oluşturmaya çalışan BRICS ülkeleri öncelikli olarak ekonomik alanda değişim öngörmüşlerdir. CRA ve NDB'nin kurulması ile ABD'nin WB ve IMF'de oynadığı merkezi rolüne ve doğrudan batı-egemen ilgili kuruluşlara karşı daha çok kendi beklentilerini yansıtan bir uluslararası düzen ön gördükleri iddia edilebilir (Jash, 2017). Göze çarpan durum NDB ve CRA'nın BRICS'e kurumsal bir kimlik sağlamış olmasıdır (Jash, 2017). NDB'yi WB'den ayrı kılan şey, IMF'de olduğunun tersine, NDB fonlarını politik şart koşmadan vermektedir (Roychoudhury ve Costa Vazquez, 2016). Politik şart koşmadan vermesi birçok ülkenin ilgisini BRICS'e doğru yönlendirebilecektir. Bu anlamda, BRICS'in sağladığı krediler az gelişmiş ülkeler üzerinde etkili olacaktır ve ekonomi alanında atılan atımlar mevcut eski sistemin donörlerine karşı da bir meydan okuma niteliği taşıdığı da söylenebilir. (Jash, 2017). İlerleyen yıllarda NDB ve CRA'nın BRICS'e değerli bir platform oluşturabileceği ve NDB ve CRA küresel ekonomik gelişimde IMF ve WB kadar bir rol oynayabileceği ve onların yerine geçebileceği iddia edilmektedir (Jones, 2015: 2-4). Fakat, gelecekte BRICS genişlemesi söz konusu olsa bile BRICS ülkelerinin hisseleri toplamda \%55'ten aşağıya düşmeyeceği de önemli bir noktayı oluşturmaktadır (Ayar, 2014).

Yedinci BRICS zirvesi Rusya'nın Kırım'1 ilhak etmesi üzerine hem Rusya'ya destek sağlamak hem de dünyaya mesaj vermek amacıyla 9 Temmuz 2015'de Rusya'nın Ufa şehrinde gerçekleştirilmiştir. Bu zirve ilk olarak bir önceki zirvelerde imzaları atılmış olan NDB ve CRA’ nın faaliyete geçeceğini bildirmektedir. Bankanın 2016 itibari ile yatırım projelerine ve özel sektöre kredi verebileceği öngörülmüştür. Bu tarz bir adım ile, BRICS kimliği altında gelişmekte olan ülkelerle etkileşim kurulması ve etki alanını genişletme düşüncesi daha çok hâkim olmuş olabilir. Etki alanlarını genişletmek ve iş birliğine katılan aktörleri çoğaltmak amacıyla Avrasya Ekonomik Birliği, Şangay İş Birliği Örgütü ve örgütün gözlemci ülkelerini bir araya getirecek bir toplantı düzenleneceği kararlaştırılmıştır. İran ile sürdürülen nükleer müzakereler sonucunda imzalanan hareket planın da desteklediklerini bildirmektedirler. Birçok zirvede İran'a yönelik destek mesajları belirtmeleri, ABD'nin İran'a yönelik hamlelerinden rahatsızlık duydukları anlamına gelir. Ayrıca, Kırım'ın ilhakı üzerine Ukrayna'da başlayan çatışmalar da Ukrayna'ya yönelik olarak askeri seçeneği kabul etmeyeceklerini belirtmeleri de bu bakımdan değerlendirilebilir. Bu bağlamda Şubat 2015'de imzalanan ve Rusya, Almanya, Fransa, Ukrayna ve BM Güvenlik Konseyi tarafından benimsenen Minsk Anlaşmasına uyulması için çağrıda bulunmuşlardır (BRICS Information Centre, 2015).

Sekizinci BRICS zirvesi Hindistan'ın Goa şehrinde 15-16 Ekim 2016 tarihlerinde gerçekleştirilmiştir. Bu zirvede, Yeni Kalkınma Bankası'nın enerji projelerine verdiği ilk krediden dolayı duyulan memnuniyet dile getirilmiştir. Verilen bu ilk kredi, BRICS ülkeleri arasında gerçekleştirilmiştir. ${ }^{11} \mathrm{Bu}$ zirvede ekonomik ve ticari bağları genişletmek için Bengal Körfezi Çok Sektörlü Teknik ve Ekonomik İş Birliği Girişimi ${ }^{12}$ (BIMSTEC) ile birlikte bir zirve düzenleyeceklerini kararlaştırmışlardır. İlk zirveden bu yana kendi aralarındaki ekonomik ve finansal iş birliği girişimlerinin olumlu sonuç vermeye başladığını belirtmektedirler. Bu noktada yabancı derecelendirme kuruluşlarının BRICS ülkelerinin notunu düşürmesi üzerine, bu zirve 'de BRICS ülkeleri kendi derecelendirme kuruluşlarını kurma kararını almışlardır (BRICS Information Centre, 2016).

\footnotetext{
11300 milyon dolar, Brezilya'ya, 250 milyon dolar Hindistan'a, 180 milyon dolar Güney Afrika'ya, 81 milyon dolar da Çin'e kredi verilmiştir.

12 BIMSTEC Ülkeleri: Bangladeş, Bhutan, Hindistan, Myanmar, Nepal, Sri Lanka ve Tayland.
} 
Dokuzuncu BRICS zirvesi Çin'in Xiamen şehrinde 4 Eylül 2017 tarihinde gerçekleştirilmiştir. Zirvedeki dikkat çeken kararlardan biri BRICS ülkeleri tüm alanlarda karşılıklı olarak tüm sektörlerdeki insanların karşılıklı değişimine yer vereceklerini açıklamalarıdır. Böylelikle toplumsal alanda da iş birliğini sürdürme hedefi ortaya konulmaktadır. IMF'de 2019 Eylül ayında yapılacak olan toplantıda ilgili reformların hayata geçirilmesini talep etmektedirler. Güney Afrika'nın gruba katılması ile birlikte Afrika'ya yönelik BRICS grubunun ilgisi arttığı için ve BRICS ülkeleri NDB'nin ilk bölgesel merkezini Güney Afrika'da açmaya karar vermişlerdir. Yine CRA çatısı altında BRICS ülkelerinin makroekonomik politikalarının uyumlaştırılması için bilgi sistem kurulmuştur. Bu zirvede yaşanan terör olaylarından dolayı, tüm ülkelerin katılımına açık terörizme karşı uluslararası koalisyon çağrısında bulunmuşlardır (BRICS Information Centre, 2017).

Onuncu BRICS zirvesi Güney Afrika'nın Johannesbutg kentinde 25-27 Temmuz 2018 tarihleri arasında düzenlenmiştir. Kapsamlı Büyüme ve Paylaşılan Refah temasıyla düzenlenen zirve, genel itibariyle çoğulculuk, siyasi ve ekonomik küresel yönetişim ve ortak sorunlar başlıklarını ele alan bir deklarasyon ile bitmiştir. Bu deklarasyonda diğer zirvelerden farklı olarak ortaya çıkan dikkat çekici ilk şey BRICS ülkeleri, Afrika kıtasının kalkınmasını ve gelişmesini devamlı hale getirebilmek için iş birliğine gitmişlerdir. Örneğin, Afrika'nın gelişimi için Yeni Ortaklık programı ve Afrika'daki alt yapıların güçlendirilmesi için ise Altyapı Programı ayrı bir program olarak kabul edilmiştir. İkinci olarak, Afrika ülkeleriyle doğrudan bağlantılı olarak, BRICS ülkeleri BM'nin etkinliği eleştirilerek, BM etkinliğinin arttırılması için, Afrika ülkelerinin BM'de özellikle güvenlik ve barış sorunlarında yeterince katılamadığını, bu ülkelerinde ilgili alanlara katılmaları gerektiğine dikkat çekmişlerdir. Güvenlik ve barış alanında yapılan vurguya ilaveten, bu alanda Hindistan ve Brezilya'nın da önemli oranda katkıda bulunabileceği ifade edilmiştir. Üçüncü olarak, dünyada devam ede gelen ve uluslararası barış ve güvenliği ilgilendiren birçok sorunu ele almışlar ve bu sorunların çözülmesinde dünyanın kendilerine ihtiyaç duyduklarını belirtmişlerdir. Bir başka nokta, BRICS ülkeleri arasında finans politikalarının uyumlaştırılması gerekliliğine yapılan vurguda dikkat çekicidir. Özellikle, üstü kapalı bir şekilde ABD’nin faizleri arttırmak (BBC, 2018) gibi finans alanında attığı adımlara dolaylı olarak atıf verilmesi de önemli olarak görülmelidir. Bu alanda yapılacak düzenlemelerin daha kapsamlı bir şekilde, ilgili uluslararası örgütler ve diyalog yoluyla yapılması yönünde önerilerde bulunulmaktadır (BRICS Information Centre, 2018).

Bu zirvede gerçekleşen diğer bir ilk ise Dünya Ticaret Örgütü (DTÖ) ile ilgilidir. BRICS ülkeleri, DTÖ’ye üye devletlerden DTÖ kurallarının tam olarak uygulanmasını istemektedirler. Çünkü, üye ülkeler arasındaki anlaşmazlıkların artması ve çözüme kavuşturulmasının uzaması, ABD ve Çin arasında serbest piyasa kurallarının çiğnenmesi hakkında gerçekleşen suçlamalar gibi durumlar (Abay ve Yıldırım, 2018) önemli derecede etkili olmuştur. Benzer şekilde, DTÖ örgütünde müzakere sisteminde yaşanacak değişikliğe de BRICS ülkeleri karş1 çıkmaktadır. Yani, müzakerelere temyiz yolu seçeneğinin getirilmesini istememektedirler (BRICS Information Centre, 2018).

Bir diğer husus, diğer zirvelerde dile getirilen ve bu zirvede memnuniyetle karşılanan Güney Afrikalı Lesetja Kganyago'nun IMF'de önemli bir konum olan Uluslararası Para ve Finans komitesinin başkanı olarak atanması, kısmen de olsa BRICS ülkelerinin ekonomik uluslararası örgütlerde dikkate alındığı iddia edilebilir. (BRICS Information Centre, 2018).

Bir başka nokta NDB'nin kurulmasıyla birlikte, NDB'nin oynadığı rolün genişlemesine de bu zirvede vurgu yapılmıştır. Özellikle NDB'nin özel sektörü finanse etmede ${ }^{13}$, diğer uluslararası örgütlere nazaran dengeleyici konuma gelmesi, Bankanın kısa süre içerisinde etkinlik alanını arttırması ile birlikte, diğer ülkeler nezdinde de kabul görmeye başladığı iddia edilebilir (BRICS Information Centre, 2018).

\section{BRICS'E YÖNELİK ELEŞTİRILER}

Bazı araştırmacılar, BRICS ülkelerindeki bir takım temel farklılıklardan dolayı BRICS'in fikirlerinde bir birlik ve ticaret, enerji fiyatlandırması ve reform taleplerinde bir açıklık olmadığını, bundan dolayı bir grup olarak etkisiz olacağını düşünmektedirler (Iqbal ve Rahman, 2016: 229). Fakat, BRICS ülke liderleri bu durumun farkında olmaları gerek ki, BRICS grubunun oluşumundan bu yana iş birliğine konu alanlar önce ekonomik alanda başlamışken, BRICS ülkeleri bugün kendi aralarında enerji, sağlık, çevre, sosyal ilişkiler, siber güvenlik, vergi, turizm vb. birçok alanda iş birliği gerçekleştirmektedirler. Özellikle finansal açıdan, BRICS ülkelerinin ilgili

13 Örneğim, Yeni Kalkınma Bankası 2016 ve 2018 yılları arasında 8 trilyon dolar vermiştir. 2019 yılı için 7.5-8 trilyon dolar arası ve 2021 yılının sonuna kadar da 35-40 trilyon arası kredi vereceği öngörülmektedir. 
alanlardaki bakanları kendi aralarında iş birliğini ve koordinasyonu güçlendirmek ve bir birliktelik oluşturmak amacıyla her yıl zirve düzenleyerek bir araya gelmektedirler. Son BRICS zirvesinde, ilgili ülkeler ulusal para birim tahvil fonuda oluşturmaya karar vermişlerdir Ayrıca, çeşitli alandaki ilişkilerinde derinleştirme eğiliminde olmaları durumu da dikkat çekmektedir. Örneğin, ilgili ülkeler enerji araştırma platformu, yeni endüstri devrimi ortaklığı, vergi dairesi gibi ortak yapılara yönelmektedirler.

BRIC ülkelerine heterojen bir iş birliği noktasında da eleştiri gelmektedir. BRICS ülkelerinin farklı politik ve ekonomik sistemlere sahip olduklarını (Armijo, 2007: 7) ve ortak bir kimliklerinin olmadığı (Brütsch ve Papa, 2013: 306) düşünülmektedir. Otokratik yönetim anlayışına sahip olmalarının yanında ayrıca, diktatör liderlere karşı fazla yumuşak söyleme sahip oldukları, insan hakları ve demokrasinin tehlikeli olduğu yerlere karşı yumuşak huylu oldukları da söylenmektedir. Fakat yöneltilen bu eleştiriler karşısında BRICS ülkeleri de Batılı ülkelere Venezuela (2002), Honduras (2009) ve Mısır'daki (2013) diktatörlere yönelik tavırlarını hatırlatmaktadırlar (Stuenkel, 2016: 8). Her ne kadar çok taraflılıktan yana olsalar da ve ABD’nin kuraları çiğnediğini söyleseler de Çin'in de bazen kural yıkan ülke olduğu hatırlanmalıdır (Stuenkel, 2016: 4).

Bir başka eleştiri ise, mevcut ekonomik düzenin yıkılıp yıkılmayacağıdır. Bu noktada, BRICS ülkeleri şimdiki neo-liberal düzene karşı meydan okuyamayacakları, böyle bir isteklerinin de zaten söz konusu olmadığı düşünülmektedir. Çünkü mevcut sistemin sağladığı faydaları kaybetme korkusunu göz önüne alarak bir hesap yapmaları gerekeceği için bunun olması şu anda mümkün görünmeyebilir. Ayrıca, mevcut sistem ABD'nin ekonomik olarak çökmesini de kaldıramayabilir (Uzgel, 2017). G. John Ikenberry'nin söylediği gibi, mevcut düzene 'katılmak kolay, devirmek zordur." (Ikenberry , 2006: 343). BRICS gibi yükselen güçlerin mevcut neoliberal düzenden faydalandığıdır (Stuenkel, 2016: 41). Çin ve Hindistan gibi ülkeler doğrudan bu düzen içine entegre oldukları için, mevcut düzeni yıkmaya yönelik bir girişim çok düşünülmemektedir. Zaten her bir BRICS ülkesinin Batılı devletler ile güçlü ekonomik bağları (Imamverdiyeva, 2014: 45) bulunmaktadır. Bu ülkelerin hızlı ekonomik gelişimlerinin nedenlerinden bir tanesi de mevcut neo-liberal düzendir. BRICS ülkeleri mevcut düzenden faydalanmakla birlikte, işin yönetişim kısmında kendilerini görmek istemektedirler.

Bazı araştırmacılara göre BRICS grubunun varlığı uluslararası sistemde, uluslararası örgütlerde ve dünya yönetiminde batı üstünlügüne karşı ciddi bir meydan okuma teşkil edebileceği ifade edilmektedir (Petropoulosa, 2013: 70-88). Çünkü kendilerini mevcut durumda 'küresel yönetişimin anahtar aktörü' (Rieck, 2016: 9) olarak göstermektedirler. Yukarıda da belirtildiği üzere, ekonomik-finansal meselelerde G20'yi önceleyen bir tavır ortaya koyup, WB ve IMF'de reform yapılmasını savunmaktadırlar. WB ve IMF'de ABD'nin tek başına sahip olduğu üstünlüğün değiştirilmesi yönünde bir görüş ortaya koymaktadırlar. Ayrıca, IMF ve WB başkanlarının artık Avrupa'dan ve ABD'den değil yükselen ekonomilerden birisi olması gerektiğini de belirtmektedirler. Ayrıca, BRICS ülkeleri dolara olan bağımlılıklarını azaltmak amacıyla, BRICS ülkelerinin kalkınma bankaları birbirlerine kendi ulusal para birimleri üzerinden kredi vermesi noktasında anlaşmışlardır (Elbasan, 2011). Fakat BM Güvenlik Konseyi'nde, IMF ve WB'de istenilen reformlar gerçekleşmemiştir. Buda BRICS ülkelerinin en büyük başarısızlığı olarak görülebilir.

\section{SONUÇ: BRICS YENI BİR DÜZEN GETIRIYYOR MU?}

BRICS ülkeleri, yeni bir düzen mi oluşturmak istiyorlar sorusu, bu çalışmanın hipotez sorusunu oluşturmaktadır. $\mathrm{Bu}$ soruya cevap verilmesi için yeterli veriler bulunmamaktadır. Ama BRICS ülkeleri kendilerinin küresel sistemde daha çok katılabilecekleri ve kendileri açısından yönetişimin kusurlu görülen yanlarında reform istemektedirler. Bu noktada artık BRICS devletleri, yönetişimin yükselen ve büyüyen ülkeleri de kapsayacak şekilde genişletilmesinden yanadırlar. Bu bağlamda örneğin BM'de eğer reform yapılacaksa kalıcı üye sayısının genişletilmesi ve daimî üyelerin oy niteliklerinin değiştirilmesi yönünde bir isteğe daha olumlu bakabilirler. Bu durumda yeni kalıcı üyelerin Brezilya, Hindistan ve Güney Afrika olması beklenebilir. Çünkü neredeyse her zirvede Brezilya, Hindistan ve Güney Afrika'nın uluslararası meselelerin çözümüne yapacağı katkının önemine değinilmektedir. Oy niteliğinin değiştirilmesi huşunda ise, kalıcı üyelerin veto haklarının değiştirilmesinden veya kaldırılmasından yana bir tavır ortaya konması beklenebilir.

WB ve IMF'de ise BRICS ülkeleri, ABD’nin tek taraflı üstünlüğünün değiştirilmesinden yanadırlar. Çünkü belirtildiği üzere, ABD'nin ilgili uluslararası örgütlerdeki oy hakkı, diğer ülkelerin ABD olmaksızın karar almalarını engellemektedir. Ayrıca, bu iki kuruluşun başkanlarının da batı merkezli olmaktan çıkmasını talep etmektedirler. Başkanların belirlenmesinde, batı dışındaki ülkelerin öne çıkmasını beklemektedirler. Sonuç 
itibariyle, BRICS ülkeleri şu an için küresel yönetişimin bazı noktalarının artık değiştirilmesini talep ettikleri iddia edilebilir.

BRICS ülkeleri ABD’nin politik ve ekonomik alanda sahip olduğu üstünlüğe karşı bir duruş sergilemekte midirler sorusu da burada anlamlı olacaktır. Hem politik hem de ekonomik alanda sorunun cevabı evettir. Özellikle ilk zirveden bu yana çok kutuplu bir uluslararası sisteme dikkat çekilerek tek taraflılıktan duyulan memnuniyetsizliklerini ifade etmektedirler. IMF, WB, BM Güvenlik Konseyi'ndeki reform taleplerinin bir boyutunu mevcut üstünlüğe karşı bir çıkış olarak da görülebilir. Çünkü ilgili örgütlerle bir şekilde ABD dünyayı yönetme idaresini elinde bulundurmaktadır. Reform düşüncesi ile hareket eden BRICS ülkeleri, durumu kendi avantajlarına çevirmeyi düşünmektedirler.

Çin ve Rusya'nın BM Güvenlik Konseyi'nde üye olmasına rağmen Güvenlik Konseyi yapısında reform istemeleri dikkat çekmektedir. Her iki ülke de küresel sorunların çözümünde BM gibi merkezi konumdaki bir uluslararası örgütün işlevsiz kaldığını düşünmektedirler. BM Güvenlik Konseyi hali hazırda egemen eşitlik ilkesine halel getiren bir durumdadır. Ayrıca, daimî üyelerin sahip olduğu çifte veto nedeniyle uluslararası barış ve güvenliği ilgilendiren meseleler ilgili ülkelerin iki dudağının arasından çıkacak olumlu görüşe bağlı olarak işlevsel olabilecektir. BRICS ülkeleri BM kurulduğundan bu yana 74 yıl geçtiği için artık 74 yıl öncesinin güç dengesini yansitan bir BM, görmek istememektedirler

BRICS platformu ilgili ülkelere uluslararası sosyalleşme, uluslararası norm ve hukuk oluşturma, dış politika araçlığı, diplomasi ve müzakere kültürü, çok taraflılık, bilgi sağlama, karşılıklı ve sürekli denetim, kamuoyu oluşturma, temsil, uluslararası görünürlük, prestij sağlama gibi noktalarda önemli işlevleri yerine getirmektedir (Ateş, 2012: 37-48).

BRICS ülkelerinin başarısını ve geleceğini etkileyebilecek birkaç noktanın altı çizilmesi gerekmektedir. Mevcut durumda uluslararası örgütlere ilişkin istenilen reformlar gerçekleşmediği için, uluslararası alanda ortak bir vizyon ile hareket etmek, amaçlara ulaşmak için önemlidir. Rusya'nın Kırım ilhak etmesin de veya NATO’nun Libya'ya karşı askeri harekatlarında olduğu gibi ortak sesle konuşmak etkili olacaktır. Bir diğeri, mevcut ekonomik büyümenin devam ettirilip ettirilemeyeceği noktasındadır. Güney Afrika hariç, diğer BRICS ülkeleri 2050 y1lına kadar dünyanın ilk 10 ekonomisi içerisinde yer alacağı tahmin edilmektedir. Dolayısıyla mevcut ekonomik büyüme devam ettikçe, diğer alanlarda etkili olunabilecektir. Ekonomik açıdan taşıdıkları potansiyel, onları küresel ekonomik sorunların çözümünde göz ardı edilemeyecek aktörler yapmaktadır.

Mevcut politikaların devam ve başarısı açısından BRICS ülkeleri arasında sosyal ilişkilerin geliştirilmesi de önemlidir. Özellikle son zirvede bu duruma vurgu yapılmıştır. People to People başlığına yer verilen deklarasyonda, iş birliğinin dar bir çerçevede kalmayacağını ve aynı zamanda BRICS grubunun varlığının daha uzun süreli olarak tasarlandığ 1 iddia edilebilir.

Her zirvede belirtildiği üzere diğer ülkelerle iş birliği yapmak istediklerini açıkça ifade etmektedirler. Yapılacak iş birliğinde ülkeleri doğrudan BRICS grubu içine dahil etmeden, ilgili ülkelerle veya kuruluşlarla bir ortaklık ya da dayanışma programı tesis ederek bağ oluşturmak istemektedirler. Dokuzuncu zirveye Mısır, Gine, Meksika, Tayland ve Tacikistan liderlerinin davet edilmesi ve görüşmelerin 'BRICS Plus' adıyla yapılacak olması örnek olarak gösterilebilir. Böyle bir durumda hem kendi pozisyonlarını güçlendirmiş olacaklar hem de etki alanlarını genişletme imkanına sahip olacaklardır.

\section{KAYNAKÇA}

AA (2017). BRICS Liderler Zirvesi Yarın Çin'de Başlıyor, http://aa.com.tr/tr/dunya/brics-liderler-zirvesi-yarincinde-basliyor/899949?amp=1, (Erişim Tarihi: 17 Kasım 2018).

Abay E. ve Yıldırım G. (2018). Dünya Ticaret Örgütü’nde Tartışmalar 24. Yılında da Devam Edecek, https://www.aa.com.tr/tr/analiz-haber/dunya-ticaret-orgutunde-tartismalar-24-yilinda-da-devamedecek/1352673, (Erişim Tarihi: 16 Mayıs 2019).

Ağır, H., ve Yıldırım, S. (2015). "Türkiye ile BRICS Ekonomilerinin Makroekonomik Performans Kaşılaştırıması: Betimsel Bir Analiz”, Kahramanmaraş Sütçi İmam Üniversitesi Dergisi, 12(2), 39-66.

Aktaş, M. (2014). “Avrupa'da Yükselen İslamofobi ve Medeniyetler Çatışması Tezi”, Ankara Avrupa Çalışmaları Dergisi, 13(1), 31-54. 
Araz, S. (2015). Küresel Güney ve BRICS Ülkeleri, http://akademikperspektif.com/2015/02/25/kuresel-guney-vebrics-ulkeleri/, (Erişim Tarihi: 30 Ekim 2018).

AREM (2012). Küresel Eğilimler: 2030 Alternatif Dünyalar, http://www.arem.gov.tr/kuresel-egilimler-2030alternatif-dunyalar, (Erişim Tarihi: 30 Kasım 2018).

Arı, T. (2004). Uluslararası İlişkiler ve Dış Politika, İstanbul: Alfa Yayınları.

Armijo, L. (2007). “The BRICS Countries As Analytical Category: Mirage or Insight?”, Asian Perspective, 7-42.

Ateş, D. (2012). Uluslararası Örğütler Devletlerin Örgütlenme Mantı̆̆ı, Bursa: Dora Yayınları.

Ayar, S. (2014). BRICS Kalkınma Bankası Ne Anlama Geliyor, http://www.abhaber.com/brics-kalkinma-bankasine-anlama-geliyor/, (Erişim Tarihi: 19 Kasım 2018).

BBC (2018). ABD Yüksek Mahkemesi Trump'ın Seyehat Yasağını Onayladı, https://www.bbc.com/turkce/haberler-dunya-44614717, (Erişim Tarihi: 2 Kasım 2018).

BRICS Information Centre (2009). Joint Statement of the BRIC Countries' Leaders, http://www.brics.utoronto.ca/docs/090616-leaders.html (Erişim Tarihi: 1 Kasım 2018).

BRICS Information Centre (2010). 2nd BRIC Summit of Heads of State and Goverment Joint Statement, http://www.brics.utoronto.ca/docs/100415-leaders.html, (Erişim Tarihi: 1 Kasım 2018).

BRICS Information Centre (2011). Sanya Decleration, http://www.brics.utoronto.ca/docs/110414-leaders.html, (Erişim Tarihi: 3 Kasım 2018).

BRICS Information Centre (2012). BRICS and Africa: Partnership for Development, Integration and Industrialisation, http://www.brics.utoronto.ca/docs/130327-statement.html, (Erişim Tarihi: 11 Kasım 2018).

BRICS Information Centre (2013). Media Note on the Informal Meeting of BRICS Leaders: Ahead of the G20 Summit in St. Petersbutg, http://www.brics.utoronto.ca/docs/130905-note.html, (Erişim Tarihi: 11 Kasım 2018).

BRICS Information Centre (2014). The 6th BRICS Summit: Fortaleza Decleration, http://www.brics.utoronto.ca/docs/140715-leaders.html, (Erişim tarihi: 13 Kasım 2018).

BRICS Information Centre (2015). VII BRICS Summit: 2015 Ufa Decleration, http://www.brics.utoronto.ca/docs/150709-ufa-declaration_en.html, (Erişim Tarihi: 14 Kasım 2018).

BRICS Information Centre (2016). 8th BRICS Summit: Goa Decleration, http://www.brics.utoronto.ca/docs/161016-goa.html, (Erişim Tarihi: 29 Kasım 2018).

BRICS Information Centre (2017). BRICS Leaders Xiamen Decleration, http://www.brics.utoronto.ca/docs/170904-xiamen.html, (Erişim Tarihi: 29 Kasım 2018).

BRICS Information Centre (2018). BRICS in Africa: Collaoration for Inclusive Growth and Shared Prosperity in the 4th Industrial Revolution, http://www.brics.utoronto.ca/docs/180726-johannesburg.html, (Erişim Tarihi: 16 Mayıs 2018).

Brütsch, C. ve Papa, M. (2013). "Deconstructing the BRICS: Bargaining Coalition, Imagined Community, or Geopolitical Fad", The Chinese Journal of International Politics, 299-327.

Chen, R. (2003). "China Perceives America: Perspectives of International Experts". Journal of Comtemporary China 12(35), 285-297.

Chris, A. ve Vieira, M. (2005). The New Diplomacy of the South: South Africa, Brazil, India nad Trilateralism, Oxford: Routledge.

CIA. (2009). The World Factbook, https://www.cia.gov/library/publications/the-world-factbook/index.html, (Erişim Tarihi: 12 Ekim 2018).

CIA. (2017). The World Factbook, https://www.cia.gov/library/publications/the-worldfactbook/rankorder/2253rank.html, (Erişim Tarihi: 12 Ekim 2018). 
CIA. (2017). The World Factbook, https://www.cia.gov/library/publications/the-worldfactbook/rankorder/2244rank.html, (Erişim Tarihi: 12 Ekim 2018).

Çelik, M. (2017). Devletlerin Egemen Eşitliği: Bir Uluslararası İlişkiler Miti, Ankara: Nobel Akademik Yayıncılık.

Doğan, F. (2017). Çin'in Hegemonik Yükselişi: Pax Americana'dan Pax Sinica'ya, Ankara: Orion Kitapevi.

Dünya (2018). Nato Zirvesine Trump Gölgesi, https://www.dunya.com/dunya/nato-zirvesine-trump-golgesihaberi-421311, (Erişim Tarihi: 5 Kasım 2018).

Ekrem, E. (2012). “ABD’nin Çin Politikası: Obama Yönetiminin Güvenlik Stratejisi”, Stratejik Düşünce, 40-45.

Ekrem, E. (2013). ABD Hegemonyasının Çöküşü ve Çin, http://www.sde.org.tr/tr/authordetail/2030-abdhegemonyasinin-cokusu-ve-cin/1210, (Erişim Tarihi: 1 Aralık 2018).

Elbasan, P. (2011). Çok Kutuplu Bir Dünyaya Doğru, http://www.bilgesam.org/incele/86/-brics--cok-kutuplu-birdunyaya-dogru/\#.WhXe20pl_IU, (Erişim Tarihi: 2 Aralık 2018).

Euronews (2017). Nato Zirvesine Trump'ın Gafları Damga Vurdu, https://tr.euronews.com/2017/05/26/natozirvesine-trumpin-gaflari-damgasini-vurdu, (Erişim Tarihi: 8 Eylül 2018)

Fukuyama F. (1992). The End of History and The Last Men, New York: The Free Press.

Ghosh, J., Havlik, P., Polawski-Ribero, M. ve Urban, W. (2009). Models of BRICs Economic Development and Challenges for EU Competitiveness, Viyana: The Vienna Institute for International Economic Studies.

Grigoriadis, I. (2010). "Friends No More? The Rise of Anti-American Nationalism in Turkey", Middle East Journal, 64(1), 51-66.

Gümüş, N. (2018). Trump Almanyayı Niye Hedef Aldı, http://www.hurriyet.com.tr/yazarlar/nilgun-tekfidangumus/trump-almanyayi-niye-hedef-aldi-40895320, (Erişim Tarihi 22 Kasım 2018).

Habertürk (2018). Ya Meksika Sınırına Duvar Yaparız Ya Da Meksika Sınırını Kapatırım, https://www.haberturk.com/ya-meksika-sinirina-duvari-yapariz-ya-da-devleti-kapatirim-1941939, (Erişim Tarihi: 5 Kasım 2018).

Hensman, R., \& Correggia, M. (2005). "US Dollar Hegemony: The Soft Underbelly of Empire. Economic and Political Weekly", 40(12), 1091-1095.

Huntington, Samuel P. (2002). Medeniyetler Çatışması, M. Yılmaz (Der.), Ankara: Vadi Yayınları.

Hurrell, A. (2006). "Hegemony, Liberalism and Global Order: What space for would- be great powers?", International Affairs, 82(1), 1-19.

Ikenberry, G. (2006). Liberal İnternational Theory in the Wake of 9/11 and American Unipolarity Five Years On. Oslo, Princeton: Princeton University Press.

Ikenberry, G. (2012). Liberal Leviathan: The Origins, Crisis and Transformation of the American World Order, Princeton: Princeton University Press.

Imamverdiyeva, U. (2014). BRICS in a Changing World: Limits and Possibilities of an Informal Institution, Yüksek Lisans Tezi, Zirve Üniversitesi Sosyal Bilimler Enstitüsü, Gaziantep.

Iqbal, B. ve Rahman, M. (2016). "BRIC(S) as an Emerging Block?” R. Van Tulder, A. Verbeke, J. Carneiro, ve M. Gonzalez (Ed.), içinde, The Challenge of Bric Multinationals, içinde (227-245), Bingley: Emerald Publishing.

Isernia, P. ve Fabrinni, S. (2007). Anti Americanism: History, Causes, Themes, Oxford: Greenwood World Publishing.

Jash, A. (2017). The Emerging Role of BRICS in the Changing World, http://www.indrastra.com/2017/06/PAPER-The-Emerging-Role-of-BRICS-in-the-Changing-WorldOrder-003-06-2017-0054html, (Erişim Tarihi: 9 Kasım 2018).

Jones, S. (2015). Financing Gloval Development: The BRICS New Development Bank, Bonn: German Development Institute. 
Kagan, R. (2014). Tarihin Geri Dönüşü ve Rüyaların Sonu, B. Akgün, N. Akyeşilmen (Çev.), Ankara: Orion Kitapevi.

Laidi, Z. (2014). "Towards a Post-Hegemonic World: The Multipolar Threat to The Multilateral Order" International Politics, 51(3), 350-365.

Manyin, M. (2012). Pivot to the Pasific? The Obama Administration's Rebalancing Toward Asia, Washington: Congressional Research Service.

Maull, H. (2006). “The Precarious State of International Order. Asia Pasific Review”, 13(1), 68-77.

Merasheimer, J. (1990). "Bak to the Future: Instability in Europe After the Cold War", International Security, $15(1), 5-56$.

Montenegro, R. ve Mesquita, R. (2017). "Leaders or Loners? How Do the BRICS Countries and their Regions Vote in the UN General Assembly", Brazilian Political Science Review, 11(2), 1-32.

Nairn, M. (2002). “Missing Links: Anti-Americanisms”, Foreign Policy, 103-104.

Nye, J. (2015). Is American Century Over?, London: Polity Books.

Odeyemi, C. (2015). "The Responsibility to Protect (R2P) in Libya and Syria: Exploration of the BRICS Role", Journal of Global Responsibility, 229-245.

Odom, W. (2007). "American Hegemony How to Use It, How to Lose It", Proceedings of the American Philosophical Society, 151(4), 404-411.

O'Neill, J. (2001). Building Better Global Economic BRICs, Los Angeles: Goldman Sachs.

Öniş, Z. ve Kutlay, M. (2015). “Demokratik BRICS Ülkeleri: Küresel Yönetişimin Yeni Aktörleri”, Analist, 2023.

Petropoulosa, S. (2013). "Losing Grasp Over the Global Financial System: The Retreat of the North vs. the Advance of the South. Journal of Global Faultlines", 1(1), 70-88.

Pew Research Center (2017). Globally, More People See U.S. Power and Infleunce as a Major Threat, http://www.pewresearch.org/fact-tank/2017/08/01/u-s-power-and-influence-increasingly-seen-as-threatin-other-countries/, (Erişim Tarihi: 17 Ekim 2018).

Rieck, C. (2016). One Plus Four: BRICS-Ambitions for Geopolitical Reform and Chinese Dominance, Berlin: The Konrad-Adenauer-Stiftung.

Routley, N. (2014). How Many Nuclear Weapons Each Country in the World, http://www.businessinsider.com/how-many-nuclear-weapons-each-country-in-the-world-has-2017-8, (Erişim Tarihi: 22 Ekim 2018).

Roychoudhury, S. ve Costa Vazquez, K. (2016). What is New About The BRICS Led New Development Bank, https://www.devex.com/news/what-is-new-about-the-brics-led-new-development-bank-88126, (Erişim Tarihi:27 Eylül 2018).

Sayın, Y. (2016). “Arap Baharı Süreci ve Sömürgelerin Çözülmesi”, Karamanoğlu Mehmetbey Üniversitesi Sosyal ve Ekonomik Araştırmalar Dergisi, 18(30), 65-70.

Sipri (2017). Trends World Military Expenditure, https://www.sipri.org/sites/default/files/Trends-world-militaryexpenditure-2016.pdf, (Erişim Tarihi: 17 Kasım 2018).

Sputnik (2017). BRICS Bugün Toplanıyor, https://tr.sputniknews.com/asya/201709031029974852-brics-buguntoplaniyor-cin/, (Erişim Tarihi: 7 Ekim 2018).

Sputnik (2017). BRICS Bugün Toplanıyor, https://tr.sputniknews.com/asya/201709031029974852-brics-buguntoplaniyor-cin/, (Erişim Tarihi: 12 Ekim 2018).

Statistics Time (2017). Countries By Projected Gdp, http://statisticstimes.com/economy/countries-by-projectedgdp.php, (Erişim Tarihi: 18 Kasım 2018). 
Statistics Time (2017). Contries By Projected Gdp Capita, http://statisticstimes.com/economy/countries-byprojected-gdp-capita.php, (Erişim Tarihi: 18 Kasım 2018).

Stuenkel, O. (2016). "The BRICS: Seeking Privileges by Constructing and Running Mulitilateral Instutions", Global Summity, 1(1), 38-53.

Sputniknews (2018). Çin Medyası: Trump'ın Politikası ABD'nin Küresel Hegemonyasını Bitirecek, https://tr.sputniknews.com/analiz/201811091036061385-cin-abd-trump-kuresel-hegemonya/, (Erişim Tarihi: 17 Ekim 2018).

Uzgel, İ. (2017). ABD’nin Bitmeyen Düşüşü, https://www.gazeteduvar.com.tr/yazarlar/2017/07/31/abdninbitmeyen-dususu/, (Erişim Tarihi: 14 Kasım 2018).

Uzgel, İ. (2017). Doların Rezerv Para Egemengliği Sürecek, https://www.borsatek.com/dolarin-rezerv-paraegemenligi-surecek-23719h.htm, (Erişim Tarihi: 14 Kasım 2018).

Wallerstein, I. (2002). “The Eagle Has Crash Landed”, Foreign Policy, (131), 60-68.

Wilson, D. ve Purushothaman, R. (2003). Dreaming with BRICs: The Path to 2050, Los Angeles: Goldman Sachs.

Worldometers (2018). Countries in the World By Population, http://www.worldometers.info/worldpopulation/population-by-country/, (Erişim Tarihi: 5 Eylül 2018).

Zakaria, F. (2008). The Post-American World, New York: W.W.Norton. 